\title{
Ecological Restoration of Basalt quarry- the case of Timba, Gujarat
}

\author{
Rajshekhar Rao \\ Associate Professor, M.S.Ramaiah Institute of Technology, Bangalore, India.
}

\begin{abstract}
Loss of organic rich soil, loss of wild life is the result of mining. Mining causes soil damage \& destruction .To regenerate the biodiversity of the mining area it is very important to reclaim the land. Reclamation is the processes of restoring the land. Ecological restoration is the process of assisting the recovery of an ecosystem that has been degraded, damaged or destroyed. It is an intentional activity that initiates or accelerates an ecological pathway. There is always a challenge involved when undertaking restoration across large mined areas. Ecological restoration establish self sustaining ecosystem with species composition and function. The processes of natural regeneration demonstrate that Nature can achieve restoration, and develop fully functioning soil. This paper discusses the Timba,Gujrat as a case study for ecological restoration. The papers also mention the processes of ecological restoration carried out, restoration techniques to reestablish the biodiversity.
\end{abstract}

Key words: Biodiversity, Ecological Restoration, Ecosystem, Natural regeneration, restoration

\subsection{History of Timba}

\section{Introduction:}

Timba is located about $110 \mathrm{~km}$ south east of Ahmedabad, Gujrat India. Here the geological track forms the part of Pavagdh basalt deposits and has been in the past several decades. A Completely barren basalt quarry up to depth of 15 to $20 \mathrm{~m}$ was done on the site. The exhausted quarry tract is spread over an area of forty one hectares (Fig.1). The quarry operation has not only distributed the natural ecological environment but also created large unused barren and degraded land. The vegetation was in poor condition because of the poor soil strata. The forty one hectares Basalt quarry land had detoriated (Fig.2) very badly. The situation presented a unique challenge where one had to prepare a plan for the rejuvenation of entire basalt quarry land. The entire landscape has to be recreated, addressing environmental issues. The rejuvenation work on the .development proposal started from 1975 \& it took eight years to complete it

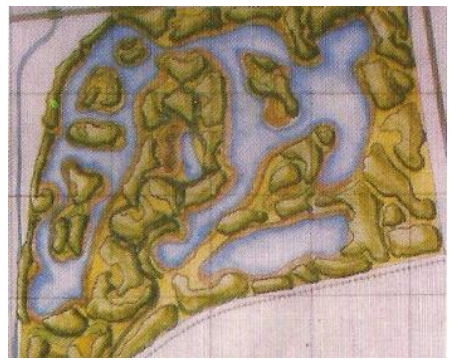

Fig 1: Site plan of Timba Basalt quarry after restoration
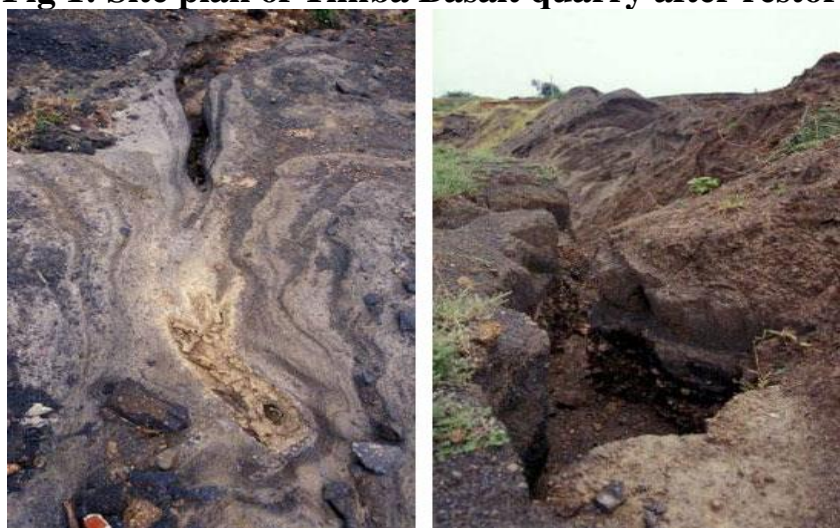

Fig.2 Timba Basalt quarry before restoration 


\subsection{Aim the Study}

To understand the condition of Basalt quarry

To understand the ecological restoration process of Basalt quarry

\subsection{Methodology:}

This study employs case study research approach to understand how the basalt quarry restoration is done using ecological approach. The data collection techniques encompass interviews, structured questionnaire, direct observation, participatory observation. Site visit are done in order to get data, to analyze the site \& to understand restoration methods.

\section{Restoration methods:}

A completely barren basalt quarry was restoration landscape design is done by $\mathrm{M} / \mathrm{S}$.Prabhakhar $\mathrm{P}$ Bhagwat Associate, a landscape firm, over a period of eight years from 1977 to 1985. In a meeting with client, landscape architects decided to convert the old quarry into nature woodland. In the initial stage suggestions from others consisted of planting the entire land with monoculture of Eucalyptus \& Leucaena Luecocephala. Later on the course of action adopted was logical.

In the beginning detailed study of Basalt quarry was carried out. This included the analysis of the natural and manmade factors affecting the ecosystem of quarry are done. Technical issues such as the effect of microclimate, topography, soil characteristics, hydrology \& the pattern of flora and fauna were considered. Factors leading to the degradation of the quarry were identified.

After a detail study of existing vegetable pattern and previous several stages, ecological seral stages, plant mix was identified that would be indigenous and one that would be sustained in the absence of any biotic interferences. The only existing vegetation was at the site was marginal scrub formation with a extremely sparse distribution of Neem trees. The first step in the processes was to enable humus formation to make the soil rich in order to sustain further vegetation cover. The ground cover would help in covering the soil moisture, rain water; keep the soil in summer months and so help to plant growth.
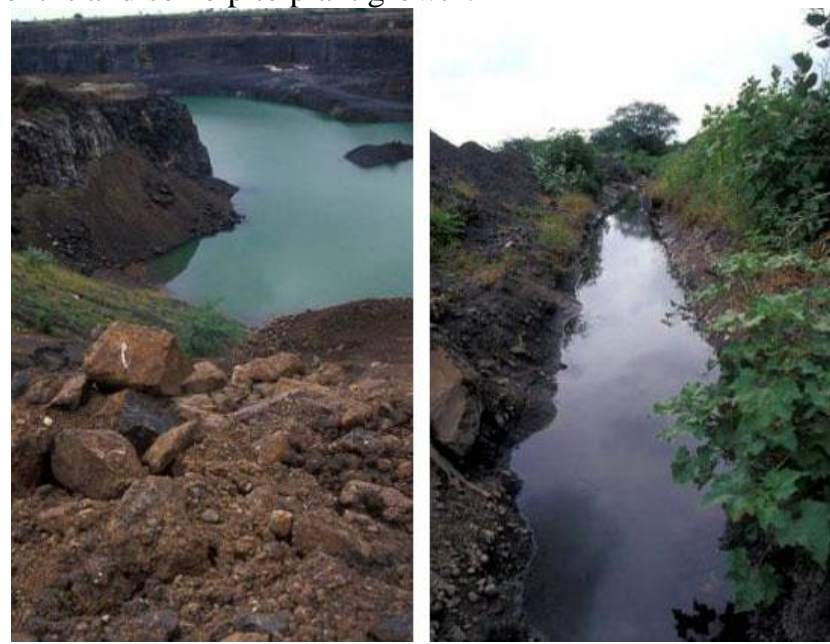

Fig 3: Timba in the processes of restoration

In order to encourage this growth, weeds from nearby areas were developed on the site. With the first shower much of the desired effect was achieved and by second year and entire area was covered with a carpet of vegetation. At the same time a list of trees was made and seedlings raised in the nursery at the site. These trees were planted in the shallow pits approximately $30 \mathrm{cmx} 30 \mathrm{~cm}$ and available organic matter was used to fill the pits. The pits were watered for a very short duration in the summer months. Soil working and mulching was done to encourage growth of plants. By the third the growth was established and more or less self sustainable. Other plants grasses and shrubs, not originally planted made their appearance in the third and fourth year. By the eight year the process was entire complete and was self sufficient in all respects. Several of the trees had flowered and seeded. Harnessing water resources within the quarry was also a critical area of work. Land contours are studied to divert rain water Shallow \& big depressions. The lake (fig.3) formed by rain water was stoked with popular varieties of fish.

\section{Findings:}

Today the entire area has become a natural environment (Fig.4) with several varieties of insects etc. approximately 140 varieties of birds visit it every year. Economically, the project has become viable with grass and other minor products paying for its maintenance and upkeep. Efforts to improve soil quality and 
introduction of native plant communities attracted butterflies followed by snakes and other fauna including migratory birds. Today the quarry has transformed in to a mature woodland without any maintenance. The processes involve commitment and patience as against natural resources. The time involved is the time needed to allow nature to recover itself.

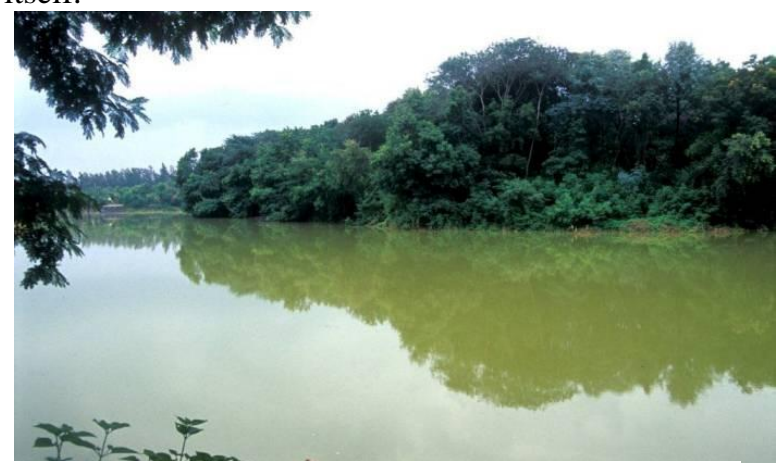

Fig.4: Timba Basalt quarry after restoration

\section{Conclusion:}

Timba basalt quarry restoration is a best example of ecological restoration. The circumstance in Timba before restoration were quite challenging and it took eight years to get green, this evidence makes it clear that ecological restoration will be a key element not only of conservation but also for sustainable development. What makes ecological restoration uniquely valuable is its inherent capacity to repair ecological damage, to get back the ecosystem. The conservation benefits of restoration are obvious. What is less apparent, but which is at least as important, is that in many instances, ecological restoration has also been able to renew economic opportunities, rejuvenate traditional cultural practices and refocus the aspirations of local communities.

\section{References:}

[1]. Allen, M.F., Jasper, D.A. \& Zak, J.C. (2002). Micro-organisms. In Perrow M.R. \& Davy, A.J. (Eds.), Handbook of Ecological Restoration, Volume 1 Principles of Restoration, pp. 257-278. Cambridge: Cambridge University Press. ISBN 0-521-79128-6

[2]. Bradshaw, A.D. (1987). Restoration: the acid test for ecology. In Jordan, W.R., Gilpin, M.E. \& Aber, J.D. (Eds.), Restoration Ecology: A Synthetic Approach to Ecological Research, pp. 23-29. Cambridge: Cambridge University Press. ISBN 0-521-33728-3

[3]. Court, Franklin E. (2012) Pioneers of ecological restoration: the people and legacy of the University of Wisconsin Arboretum. Madison: University of Wisconsin Press. ISBN 9780299286644

[4]. Harris, J.A. (2003) Measurements of the soil microbial community for estimating the success of restoration. European Journal of Soil Science. 54, 801-808

[5]. Harris, J.A., Hobbs, R.J, Higgs, E. and Aronson, J. (2006) Ecological restoration and global climate change. Restoration Ecology 14(2) $170-176$.

[6]. Jordan, William R. \& Lubick, George M. (2012) Making nature whole: a history of ecological restoration. Washington, D.C. Island Press. ISBN 9781597265126

[7]. Young, T.P. (2000). "Restoration ecology and conservation biology". Biological Conservation. 92, 73-83.

[8]. www.landscapeindia.net 